\title{
Isolation of Anaerobic Phycomycete \\ Fungi from Some Herbivores and \\ Their Chemical Composition
}

\author{
Akio Onoda, Yasuo Kobayashi, Masaaki Wakita \\ and Sadao Hoshino \\ Faculty of Bioresources, Mie University, Tsu-shi 514
}

(Received June 1, 1992)

\begin{abstract}
Anaerobic phycomycete fungi were found in gut and faecal samples from sheep, cattle, goat, sika deer, Japanese serows, the musk ox, horses and ponies. The population size of the fungi estimated by the roll tube method was of the order of $10^{3} / \mathrm{m} l$ for the gut samples and $10^{2} / \mathrm{g}$ for the faecal samples. A Neocallimastix sp. and a Piromyces sp. were isolated from sheep rumen samples and a Caecomyces sp. from horse faecal samples. The chemical composition of these isolates was examined : there were no distinct differences in amino acid and fatty acid composition among the three isolates, and the amino acid composition was similar to that of rumen protozoa. The fatty acid composition of the isolates was rich in long-chain fatty acids, especially in oleic acid, which amounted to $45 \%$ of total fatty acids $(\mathrm{w} / \mathrm{w})$ in the lyophilized samples of the Piromyces sp. The isolates all contained chitin ranging from $3.4 \%$ (Piromyces sp.) to $4.3 \%$ (Caecomyces sp.).
\end{abstract}

Anim. Sci. Technol. (Jpn.) 64 (2): 115-120, 1993

Key words: Phycomycete fungi, Herbivores, Amino acid composition, Fatty acids, Chitin

A wide distribution of anaerobic phycomycete fungi in domestic and wild herbivores has so far been reported. "1) However, we have only scanty information on fungi in herbivores which are reared or live freely in this country. It is well established that anaerobic fungi play a significant role in fiber digestion in the rumen of domestic animals ${ }^{11)}$.

On the other hand, their nutritional contributions as protein and lipid sources to the host animal are not clear. The present paper describes the isolation and enumeration of anaerobic phycomycete fungi from the gut and faeces of various animals, together with the chemical composition of these isolated fungi.

\section{Materials and Methods}

The following animals were employed for the fungal sampling : cattle (Holstein), sheep (a Corriedale $\times$ Suffolk cross), goats (Saanen), sika deer (Cervus nippon), Japanese serows (Capricornis crispus), musk ox (Ovibos moschatus), horses (Thoroughbred) and ponies. Cattle, sheep and horses were reared with appropriate roughage (hay, straw or haycube) and concentrate on the university farm. The other animals were maintained in a city park (goat and ponies) and in a mountain park in Mie prefecture with hay and wheat bran.

In sheep, fungal inoculum was prepared from ruminal and caecal contents and fresh faeces, while in cows from rumen contents and fresh faeces. In the other remaining animals, fresh faeces were used for the inoculum. Rumen and caecal contents were strained through two layers of gauze and aliquots were then sus- 


\section{Onoda, Kobayashi, Wakita and Hoshino}

pended in a diluent solution with vigorous stirring. Inocula thus prepared were inoculated into roll tubes with JoBLIN's medium ${ }^{51}$ containing streptomycin $(2 \mathrm{mg} / \mathrm{ml})$ and penicillin $\left(2 \times 10^{4} \mathrm{iu} / \mathrm{ml}\right)$, and the tubes were incubated at $37^{\circ} \mathrm{C}$ for 5 days. These procedures were carried out under anaerobic conditions. Faecal samples were treated in a manner similar to the gut samples describod above and their inocula were incubated in roll tubes to enumerate colony counts, from which zoospores in terms of number/g or $\mathrm{m} l$ of samples were calculated. Three species of phycomycete fungi were isolated through these separation experiments. Based on the morphology of zoospores, these were a Neocallimastix (N.) sp., a $P$ iromyces $(P$.$) sp. and a Caecomyces (C.) \mathrm{sp.}$, though each species name was unknown.

Each of the isolates was cultivated and submitted to analyses of chemical composition as follows. Five days after incubation, colonies developed in roll tubes were picked under anaerobic conditions, inoculated into a liquid medium described by JoBLIN ${ }^{5)}$ and incubated at $37^{\circ} \mathrm{C}$ for 5 days. Fungi thus cultivated were collected with centrifugation (1500 rpm, $5 \mathrm{~min}$ ), washed 3 times with $0.9 \%$ saline and lyophilized. Amino acids of fungal freeze dried samples were analyzed by an o-phthalaldehyde method with the aid of HPLC (Tosoh Co. ${ }^{13)}$. Medium- and long-chain fatty acids were methylated with $\mathrm{HCl}$-methanol $(5: 95, \mathrm{v} / \mathrm{v})$ and the resultant methyl esters were determined by gas chromatography ${ }^{15)}$. Concentrations of chitin in fungal samples were determined as described by CHEN and JoHNSON ${ }^{4}$. Amino acid and fatty acid composition of Entodinium protozoa and mixed rumen bacteria from the sheep rumen were also analyzed in a similar way to compare them with fungi.

\section{Results}

Anaerobic phycomycete fungi ranging from $0.2 \times 10^{2}$ to $3.4 \times 10^{3}$ were found in all tested gut and faecal samples (Table 1). Rumen samples from sheep and cows contained more numerous zoospores than the faecal samples. The number of zoospores detected in faecal samples were mostly of the order of $10^{2}$ but those from sika deer and horses were less than $10^{2}$.

The amino acid and fatty acid composition of fungal isolates is shown in Tables 2 and 3. A $N$. sp. and a $P$. sp. were isolated from sheep rumen samples, while a $C$. sp. was isolated from horse faecal samples. Amino acid analysis of the fungal isolates failed to estimate

Table 1. Enumeration of anaerobic phycomycete fungal colonies in roll tubes inoculated gut and faecal samples from various herbivores

\begin{tabular}{lccc}
\hline \multicolumn{1}{c}{ Animal } & No. of animals & Sample & No. of colonies \\
\hline Sheep (Ovis aries) & 9 & rumen & $3.4 \times 10^{3} / \mathrm{ml}$ \\
& & caecum & $0.8 \times 10^{3} / \mathrm{g}$ \\
Cattle (Bos taurus) & & faeces & $0.3 \times 10^{3} / \mathrm{g}$ \\
& 4 & rumen & $3.4 \times 10^{3} / \mathrm{ml}$ \\
Goat (Capra hircus) & & faeces & $0.8 \times 10^{3} / \mathrm{g}$ \\
Sika deer (Cervus nippon) & 1 & $\prime \prime$ & $0.6 \times 10^{3} / \mathrm{g}$ \\
Japanese serow (Capricornis crispus) & 3 & $\prime \prime$ & $0.2 \times 10^{2} / \mathrm{g}$ \\
Musk ox (Ovibos moschatus) & 2 & $\prime \prime$ & $1.0 \times 10^{2} / \mathrm{g}$ \\
Horse (Equus caballus) & 1 & $\prime \prime$ & $2.6 \times 10^{2} / \mathrm{g}$ \\
Pony (Equus caballus) & 3 & & $0.3 \times 10^{2} / \mathrm{g}$ \\
\hline
\end{tabular}


Table 2. Amino acid composition of a lyophilized sample of three fungal isolates (Neocalli$\operatorname{mastix}(N$.$) sp., Piromyces (P.) sp. and Caecomyces(C.) sp.) in comparison with sheep rumen$ ciliates and mixed rumen bacteria

\begin{tabular}{|c|c|c|c|c|c|}
\hline \multirow[b]{2}{*}{ Amino acid } & \multicolumn{3}{|c|}{ Fungus } & \multirow{2}{*}{$\begin{array}{l}\text { Rumen } \\
\text { ciliates }\end{array}$} & \multirow{2}{*}{$\begin{array}{c}\text { Mixed rumer } \\
\text { bacteria }\end{array}$} \\
\hline & N.sp. & P.sp. & C.sp. & & \\
\hline & - & - & Molar $\%$ & 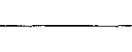 & - \\
\hline Aspartic acid & 13.0 & 13.2 & 11.7 & 13.2 & 8.6 \\
\hline Threonine & 6.9 & 6.8 & 5.7 & 5.8 & 6.0 \\
\hline Serine & 7.5 & 2.3 & 6.3 & 5.7 & 5.9 \\
\hline Glutamic acid & 13.0 & 12.6 & 13.1 & 13.7 & 8.8 \\
\hline Proline & 5.3 & 5.3 & 4.4 & 4.6 & 4.8 \\
\hline Glycine & 8.3 & 8.6 & 9.0 & 8.0 & 8.7 \\
\hline Alanine & 8.7 & 8.5 & 11.5 & 6.9 & 31.0 \\
\hline 1/2 Cystine & 0.6 & 0.3 & 0.5 & 0.1 & 0.6 \\
\hline Valine & 8.0 & 7.6 & 7.1 & 5.5 & 8.6 \\
\hline Methionine & 1.9 & 1.6 & 1.4 & 0.4 & 2.1 \\
\hline Isoleucine & 7.8 & 8.4 & 6.7 & 7.1 & 5.3 \\
\hline Leucine & ND & ND & ND & 8.4 & 8.4 \\
\hline Tyrosine & ND & ND & ND & 2.2 & 5.7 \\
\hline Phenylalanine & 5.6 & 5.1 & 6.4 & 4.6 & 5.3 \\
\hline Histidine & 2.9 & 3.1 & 3.2 & 2.0 & 1.8 \\
\hline Lysine & 6.7 & 7.5 & 9.1 & 8.3 & 4.5 \\
\hline Arginine & 3.7 & 4.0 & 3.9 & 3.5 & 4.0 \\
\hline Total & 0.49 & 0.30 & $\begin{array}{c}\mathrm{mM} / \mathrm{mg} \\
0.38\end{array}$ & 0.78 & 1.84 \\
\hline
\end{tabular}

ND : not determined

leucine and tyrosine concentrations because of the overlapping peaks of these amino acids with some glucosamines. Accordingly, the amino acid molar percent was calculated with the exception of leucine and tyrosine. The amino acid composition of the three fungal isolates was similar, with all having abundant aspartic and glutamic acids. The fungal amino acid composition was also similar to protozoal amino acid composition but the amino acid content of fungi was about one-half that of protozoa (Table 2).

There were no distinct differences in fatty acid composition among the three fungal isolates. The prominent feature of fungal fatty acid composition was a large amount of oleic acid, which was approximately 2 times as large as that of protozoa. In contrast to protozoa and bacteria, fungal samples contained a relatively high degree of medium-chain fatty acids. (Table 3 ). The chitin content of fungal isolates was as follows; $4.3 \%$ in the C. sp., $4.0 \%$ in the $N$. sp., and $3.4 \%$ in the P. sp.. Chitin, however, was not detected in either Entodinium protozoa or mixed rumen bacteria.

\section{Discussion}

This study confirmed the presence of anaerobic phycomycete fungi in foregut-fermenters (sheep, cattle, goats, sika deer, Japanese serows and the musk ox) as well as hindgutfermenters (horses and ponies). In addition to these animals, a distribution of these fungi has been found in impalas, kangaroos, elephants", reindeer and camels ${ }^{11}$. However, this is the first ever demonstration that the sika deer and Japanese serow are both herbivores maintaining strictly anaerobic fungi in the gut. 
Table 3. Fatty acid composition of lipids in a lyophilized sample of isolates (Neocallimastix (N.) sp., Piromyces(P.) sp. and Caecomyces(C.) sp.) in comparison with sheep rumen ciliates and mixed rumen bacteria

\begin{tabular}{|c|c|c|c|c|c|}
\hline \multirow{2}{*}{$\begin{array}{l}\text { Fatty } \\
\text { acid }\end{array}$} & \multicolumn{3}{|c|}{ Fungus } & \multirow{2}{*}{$\begin{array}{l}\text { Rumen } \\
\text { ciliates }\end{array}$} & \multirow{2}{*}{$\begin{array}{c}\text { Mixed rumen } \\
\text { bacteria }\end{array}$} \\
\hline & $N . \mathrm{sp}$. & P.sp. & C.sp. & & \\
\hline & & 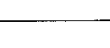 & in weig & - & - \\
\hline $12: 0$ & 6.8 & 7.7 & 9.9 & 0.6 & 1.6 \\
\hline $13: 0$ & - & - & - & 0.8 & 1.1 \\
\hline $14: 0$ & 13.6 & 10.1 & 8.4 & 2.0 & 6.0 \\
\hline$i 15: 00$ & - & - & - & - & 8.5 \\
\hline $15: 0$ & - & - & - & 1.3 & 4.2 \\
\hline $16: 0$ & 25.5 & 23.3 & 33.4 & 54.1 & 31.4 \\
\hline $18: 0$ & 12.3 & 13.8 & 15.3 & 7.6 & 39.4 \\
\hline $18: 1$ & 41.8 & 45.1 & 33.2 & 21.1 & 5.3 \\
\hline $18: 2$ & - & - & - & 12.6 & - \\
\hline $19: 0$ & - & - & - & - & 2.5 \\
\hline Total & 8.5 & 11.0 & 7.8 & 12.4 & 31.4 \\
\hline
\end{tabular}

- : not detected

The zoospore population density of sheep and cattle rumen was in the range of $10^{3} / \mathrm{m} l$, in accordance with previous reports ${ }^{5,11,14)}$. Compared to the rumen, faecal samples showed a greater decrease in zoospore population density, suggesting that rumen fungi resist outflow from the rumen and/or that most of the flowed zoospores are digested in the lower gut of the host animal.

The amino acid composition of the present fungal isolates was similar to that of rumen protozoa, indicating that fungal proteins are very excellent nutrients for host animals if notable amounts are transferred from the rumen to the intestine and hydrolyzed there. Kemp et al. "' determined the free- and proteinamino acids of $N$. frontalis and $P$. communis, and found that the amino acid profiles of the two fungi were similar and comparable to cascin and lucerne protein. In comparing our results with those of KEMP et al. ${ }^{7}$, there was reasonable consistency in amino acid profiles except for the molar percent of alanine. The minor differences in amino acid composition between fungi belonging to the same genus may be due to differences in species, growth stages and the cultivation of fungi employed.

The present fungal isolates were charactcrized by their high oleic acid content as compared to those of rumen protozoa and bacteria (Table 3). This is consistent with the data provided by BODY and BAUCHOP ${ }^{3 \text { ) }}$ and KEMP et al. $\left.{ }^{6}\right)$ which analyzed the lipids of $N$. frontalis and $P$. communis in detail. In their study ${ }^{6 !},{ }^{14} \mathrm{C}$-oleic acid as a tracer was incorporated into fungal lipids without being appreciably metabolized to other fatty acids, and nearly one-half of labelled glucose and acetate was used for oleic acid synthesis. These findings, together with the high oleic acid content in fungal lipids, suggest that rumen fungi, including the $P$. sp. as well as the $N$. sp. and $C$. sp., require this fatty acid to a greater degree. However, the functional role of oleic acid in these fungi remains to be clarified.

In the present culture condition, it is highly probable that both methanogens ${ }^{2)}$ and $\mathrm{my}$ coplasmas $^{8)}$ are associated with fungal samples, in that these associated organisms may contaminate the data on amino acid and fatty 
acid composition in Tables 2 and 3 . However, the magnitude of this contamination is obscure at present, and a chemical analysis of bacteriaand mycoplasma-free fungi remains to be determined.

The present study confirmed the presence of chitin in the fungal isolates, in good agreement with previous reports ${ }^{7,10)}$. The proportion of chitin content in our isolates varied, according to species, from $3.4 \%$ to $4.3 \%$, whereas chitin content ranging from $8-22 \%{ }^{8)}$ to $8-12 \%^{7)}$ was reported for $N$. frontalis, $P$. communis and $C$. communis. These different chitin content values are attributable to differences in analytical methods, fungal species and growth stage. Although the chitin content of our isolates was low, polyoxin (an inhibitor of chitin synthesis) completely suppressed the growth of isolates (CANN et al., unpublished), which is consistent with the case of nikkomycin on an $N . \mathrm{sp}^{9}$. This indicates that chitin plays an essential role in the growth of anaerobic phycomycete fungi, as previously reported ${ }^{11)}$.

\section{Acknowledgment}

We wish to thank Dr. K. UsHidA for his expert instruction in the isolation and cultivation of anaerobic phycomycete fungi.

\section{References}

1) BAUCHOP, T., The gut anaerobic fungi: colonizer of dietary fibre. In Fibre in Human and Anim. Nutr., (Wallace, G. and L. Bell eds.) 143-148. Royal Soc. New Zealand. Wellington. 1983.

2) Bauchop, T. and D.O. Mountfort. Cellulose fermentation by a rumen anaerobic fungus in both the absence and the presence of rumen methanogens. Appl. Environ. Microbiol., 42: 1103-1110. 1981.

3) BoDy, D.R. and T. BAuchop, Lipids composition of an obligately anaerobic fungus Neocallimastix frontalis isolated from a bovine rumen. Can. J. Microbiol., 31: 463-466. 1985.

4) Chen, G.C. and B.R. Johnson, Improved colorimetric determination of cell wall chitin in wood decay fungi. Appl. Environ. Microbiol., 46 : 13-16. 1983.

5) Joblin, K.N., Isolation, enumeration, and maintenance of rumen anaerobic fungi in roll tubes. Appl. Environ. Microbiol., 42: 1119-1122. 1981.

6) Kemp, P., D.J. Lander and C.G. Orpin, The lipids of the rumen fungus Piromonas communis. J. Gen. Microbiol., 130 : 27-37. 1984.

7) Kemp, P., D.J. Jordan and C.G. Orpin, The free- and protein-amino acids of the rumen phycomycete fungi Neocallimastix frontalis and Piromonas communis. J. Agric. Sci., Camb., 105 : 523-526. 1985.

8) Kudo, H., K.D. Jakober, R.C. Phillippe, K.-J. CHENG, D.J.S. BARR and J.W. COSTERTON, Isolation and characterization of cellulolytic anaerobic fungi and associated mycoplasmas from the rumen of a steer fed a roughage diet. Can. J. Microbiol., 36 : 513-517. 1990.

9) Lowe, S.E., G.G. Griffiths, A. Milne, M.K. Theodorou and A.P.J. Trinci, The lifecycle and growth kinetics of an anaerobic rumen fungus. J. Gen. Microbiol., $133:$ 1751-1758. 1987.

10) OrPIN, C.G., The occurrence of chitin in the cell walls of the rumen organisms Neocallimastix frontalis, Piromonas communis and Sphaeromonas communis. J. Gen. Microbiol., 99 : 215-218. 1977.

11) Orpin, C.G. and K.N. Joblin, The rumen anaerobic fungi. In The Rumen Microbial Ecosystem (Hobson, P.N. ed.) 129-150. Elsevier Appl. Sci. London and New York. 1988.

12) Phillips, M.W. and G.L.R. Gordon, Growth characteristics on cellobiose of three different anaerobic fungi isolated from the ovine rumen. Appl. Environ. Microbiol., 55 : 1695-1702. 1989.

13) Tosoh manual. Analysis of amino acid in proteins. No. 0901105 : 1-18. 1989.

14) Ushida, K., H. Thanaka and Y. KoJima, A simple in situ method for estimating fungal population size in the rumen. Letters Appl. Microbiol., 9 : 109-111. 1989.

15) Wakita, M., R. Sakauchi and S. Hoshino, Salinomycin alters cellular fatty acid composition of mixed rumen bacteria and genus Entodinium ciliates. J. Gen. Appl. Microbiol., 35 : 327-331. 1989. 


\title{
草食動物から嫌気性藻菌類の分離とそれらの化学組成
}

\author{
小野田昭雄・小林泰男・脇田正彰・星野貞夫
}

三重大学生物資源学部, 建市 514

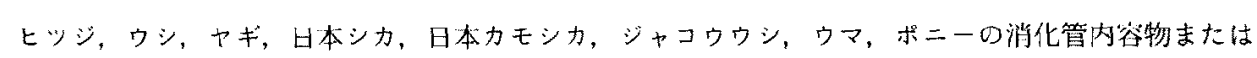
新鮮䔬から俫父性藻菌類をJoblin の培地を用いたロールチューブ法で分離した。得られた藻菌類のコ

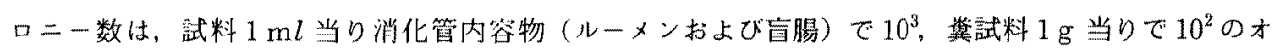
ーダーであった．ヒッジのルーメン試料から Neocallimastix 属, Piromyces 属, ウマの翼試料か らCaecomyces 属の藻菌を単離し, それらの化学組成を調べた。 アミ/酸組成は 3 種の藻菌とも類似 しており，Entodinium 属のルーメンプロトゾアのをれよよく似た組成であった．脂肪酸組成も藻菌 種間に大きな差異はないものの長銷脂肪酸，とりわけオレイン酸含量が多く, 凍結乾燥菌体の総脂肪酸 の33〜 45\% (w/w) も占めていた．また， 3 菌種とむチキンが検出でき，3.4〜4.3\% 含まれているこ 亡が分った。

日畜会報, 63 (2)：115-120,1993 